\title{
Edukasi Konsumsi Gula, Garam dan Lemak Sebagai Upaya Pencegahan Sindrom Metabolik
}

\author{
Yanti Ernalia*1, Tahrir Aulawi², Nur Pelita Sembiring3 ${ }^{3}$, Novfitri Syuryadi ${ }^{4}$ \\ 1,2,3,4 Program Studi Gizi, Fakultas Pertanian dan Peternakan UIN Sultan Syarif Kasim Riau \\ *e-mail: yanti.ernalia@uin-suska.ac.id ${ }^{1}$, tahrira@yahoo.com ${ }^{2}$, nurpelitasembiring@ymail.com ${ }^{3}$, \\ novfitri.syuryadi@gmail.com ${ }^{4}$
}

\begin{abstract}
Excess levels of sugar, salt and fat consumption due to lack of knowledge are increasing every year and have an impact on the high incidence of metabolic syndrome. It is important to share nutrition information to the Darul Amal Mosque community in Pekanbaru, which is a category of adult and elderly population who are at risk of developing metabolic syndrome. Weight and height were measured to obtain the Body Mass Index (BMI) value as indicator nutritional status. Education is done using video media, posters, and infocus media. The participants had nutritional problems, being thin (10\%), pre-obese (10\%), obese I (25\%), and Obes II (15\%). The post test results showed an increase in nutritional knowledge in the good category from $60 \%$ to 95\%. Meanwhile, the nutritional knowledge in the less category decreased from $40 \%$ to 5\%. Education went well and suggested to continue with different topics and be accompanied by practice.
\end{abstract}

Keywords: nutrition, education, food, community, metabolic syndrome

\begin{abstract}
Abstrak
Perilaku konsumsi gula, garam, dan lemak berelebihan pada masyarakat akibat kurangnya pengetahuan semakin meningkat setiap tahunnya dan berdampak pada tingginya kejadian sindrom metabolik. Penting dilakukan edukasi gizi pada ibu pengajian Mesjid Darul Amal Pekanbaru yang merupakan kategori penduduk usia dewasa dan lansia yang berisiko mengalami sindrom metabolik. Satus gizi masyarakat diperoleh dengan melakukan penimbangan berat badan dan tinggi badan dengan hasil nilai Indeks Massa Tubuh (IMT). Edukasi dilakukan menggunakan media video, poster, dan power point. Peserta pengabdian memiliki masalah gizi yaitu kurus (10\%), pra obes (10\%), obes I (25\%), dan Obes II (15\%). Hasil post test menunjukkan peningkatan pengetahuan gizi dengan kategori baik dari 60\% menjadi $95 \%$. Sedangkan untuk pengetahuan gizi dengan kategori kurang menurun dari 40\% menjadi 5\%. Kegiatan berjalan lancer, dan di sarankan terus berlanjut dengan topik yang berbeda dan disertai dengan praktek.
\end{abstract}

Kata kunci: gizi, edukasi, makanan, masyarakat, sindrom metabolic

\section{PENDAHULUAN}

Data Kementerian Kesehatan, Riset Kesehatan Dasar (Riskesdas) 2018 menunjukkan masih terdapat masalah gizi di Indonesia seperti stunting, gizi kurang, dan gizi lebih (Triple Burden) (Kemenkes, 2018). Prevalensi Sindrom Metabolik pada masyarakat pedesaan sebesar 25\% (Fenty, 2016). Prevalensi obesitas sentral sebagai salah satu kriteria sindrom metabolik di Kota Pekanbaru tertinggi dibandingkan kabupaten/kota lainnya di Provinsi Riau, yaitu 36.20\%. Prevalensi obesitas sentral di Provinsi Riau sebesar (32,5 \%) lebih besar dari rata - rata nasional (31.0\%). Secara umum prevalensi tertinggi obesitas sentral penduduk Indonesia berada pada kelompok umur 45-54 tahun (42.3\%), dan usia 35-44 tahun (39.2\%) (Kemenkes RI, 2013). Berdasarkan hasil penelitian yang dilakukan pada tahun 2014 di Pekanbaru Riau diketahui bahwa prevalensi sindrom metabolik adalah 21,5\% (Zahtamal et al., 2014). Faktor resiko Sidrom metabolik meliputi gaya hidup (pola makan, merokok, aktivitas fisik), genetik, dan sosial ekonomi (Rini, 2015)

Pandangan sikap dan pengetahuan masyarakat mengenai gizi ada yang masih keliru, misalkan dengan mengutamakan cita rasa makan yang manis, gurih cenderung asin tinggi natrium, dan gorengan yang tinggi lemak masih mementingkan rasa di bandingkan kualitas dan kuantitas gizi. Hasil analisis konsumsi gula, garam, dan lemak pada penduduk Indonesia yang 
melebihi batas konsumsi/orang per harinya meningkat setiap tahun. Anjuran konsumsi gula, garam, dan lemak untuk setiap orang dan setiap harinya berturut turut yaitu 4 sendok makan, 1 sendok teh, dan 5 sendok makan (Kemenkes R, 2013b). Berdasarkan hasil penelitian lain juga di ketahui bahwa asupan masyarakat tinggi lemak (saturated fatty acid) berhubungan dengan sindrom metabolik (Harisson et al., 2020), asupan natrium dari garam memiliki keterkaitan dengan sindrom metabolik (Al-Agili, 2020), pola makan berpengaruh terhadap kejadian sindrom metabolik (Nurzakiah, 2021), serta supan gula berlebih juga berhubungan dengan kejadian sindrom metabolik (Semnani-Azad et al., 2020). Hampir keseluruhan (97\%) responden penderita sindrom metabolik memiliki asupan lemak jenuh yang melebihi angka kecukupan gizi (Utami et al., 2014)

Kegiatan edukasi gizi dengan tema anjuran pembatasan konsumsi gula, garam, dan lemak sudah pernah di lakukan oleh beberapa tim pengabdian yang berbeda dengan sasaran kelompok yang berbeda di tempat lain contohnya pada kelompok diabetes (Ismawanti et al., 2020), usia dewasa di Daerah Istimewa Yogyakarta (Widayati et al., 2020) yang diketahui berdasarkan hasil kegiatan tersebut banyak masyarakat yang belum memahami mengenai anjuran pembatasan konsumsi gula, garam, dan lemak serta kaitannya dengan kejadian sindrom metabolik. Kegiatan edukasi gizi secara umum mengenai gizi seimbang juga pernah dilakukan di Brebes dengan hasil peningkatan pengetahuan dari 12\% menjadi 76\% (Masrikhiyah, 2020)

Berdasarkan hal diatas maka penulis ingin melakukan kegiatan pengabdian kepada masyarakat terhadap masyarakat khususnya masyarakat umum mulai dari usia dewasa, dan lansia di Mesjid Darul Amal Pekanbaru. Mesjid Darul Amal berada di lingkungan Kelurahan Tuah Madani yang merupakan bagian dari wilayah kerja Kampung Keluarga Berencana Tunas Harapan yang berdasarkan data cukup banyak terdapat penduduk usia balita, remaja sebagai calon ibu dan ibu, serta lansia sebagai kelompok yang berisiko mengalami sindrom metabolik. Edukasi mengenai pentingnya pembatasan asupan garam, gula, dan lemak ini penting dilakukan untuk mencegah sindrom metabolik yang angka kejadiannya cenderung meningkat baik di Indonesia maupun di dunia.

\section{METODE}

Kegiatan pengabdian dilakukan melelui tiga tahap yaitu persiapan, pelaksanaan, dan evaluasi. Tahap awal tim pengabdian melakukan survei pendahuluan, perizinan, menyiapkan waktu, dan tempat pengabdian, bahan materi berupa power point, video, poster, handout, spanduk, daftar hadir, sertifikat, souvenir, dan alat kegiatan berupa infocus, laptop, serta protokol kesehatan (masker, hand sanitizer, disinfektan spray), serta timbangan berat badan digital, pengukur tinggi badan mikrotoise untuk mengetahui status gizi peserta, dan kuesioner pre test dan post test yang terdiri dari lima soal pilihan ganda.

Tahapan pelaksanaan kegiatan yaitu melakukan penimbangan berat badan dan tinggi badan untuk mendapatkan data status gizi peserta, memberikan kuesioner data diri, dan pre test mengenai pengetahuan masyarakat di lokasi pengabdian mengenai sindrom metabolik beserta konsumsi gula, garam, dan lemak kepada 20 ibu peserta pengajian wirid masjid Darul Amal Pekanbaru. Tim Pengabdian melakukan edukasi gizi pembatasan konsumsi gula, garam, dan lemak sebagai upaya pencegahan sindrom metabolik dengan menggunakan media video, poster, dan power point. Tahap Evaluasi dilakukan pada akhir kegiatan ini melalui kuesioner post test. Tingkat keberhasilan juga di pantau dari respon peserta setelah kegiatan pengabdian dilakukan.

\section{HASIL DAN PEMBAHASAN}

Kegiatan pengabdian masyarakat ini dilaksanakan di Mesjid Darul Amal, Kota Pekanbaru, Provinsi Riau, pada Juni tahun 2021. Peserta berjumlah 20 orang yang merupakan ibu ibu peserta pengajian wirid masjid Darul Amal. Peserta pengabdian 
menyambut dengan baik edukasi anjuran pembatasan konsumsi gula, garam, dan lemak yang di sampaikan oleh narasumber.

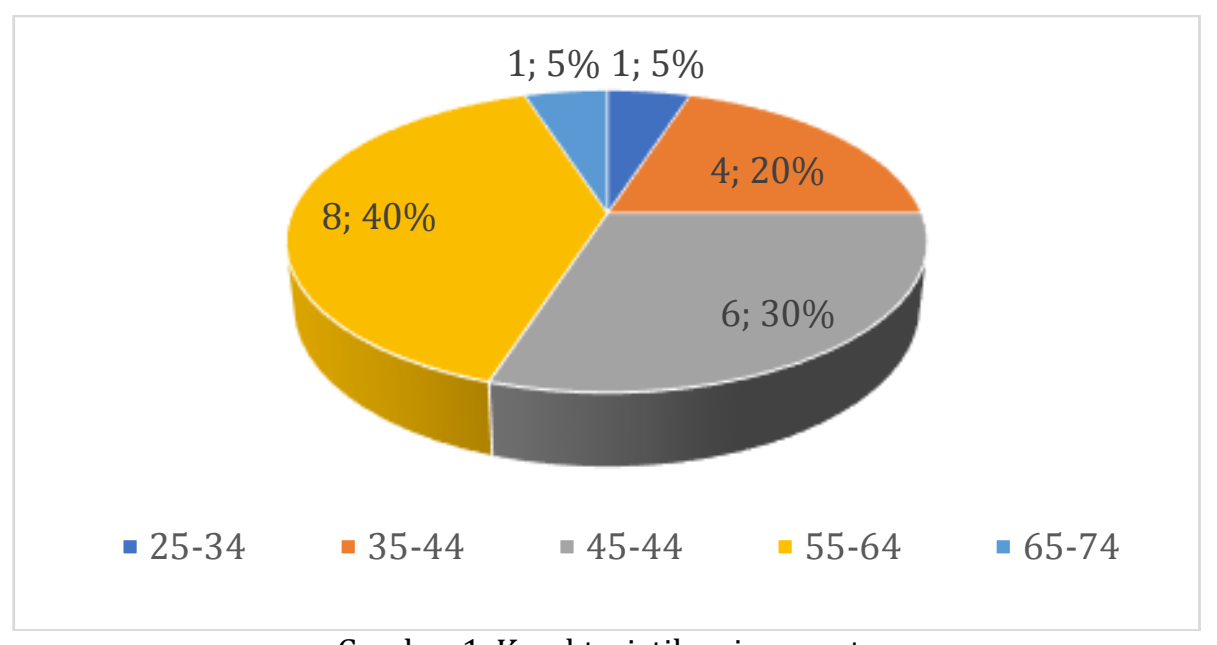

Gambar 1. Karakteristik usia peserta

Peserta pengabdian termuda usia 28 tahun dan usia peserta paling tinggi 72 tahun. Peserta cukup banyak masuk pada ketegori usia lansia ( $>55$ tahun) yaitu sebanyak $45 \%$, usia menjelang lansia 45- 54 tahun sebanyak $30 \%$, dan usia dewasa 35-44 tahun sebanyak $20 \%$. Rentang usia peserta ini sesuai dengan data bahwa prevalensi tertinggi obesitas sentral penduduk Indonesia berada pada kelompok umur 45 - 54 tahun (42.3\%), dan usia 35-44 tahun (39.2\%) yaitu sebesar 42.3\%, dan usia 35-44 tahun sebesar 39.2\% (Kemenkes RI, 2013)

Berdasarkan nilai Indeks Massa Tubuh (IMT) kriteria WHO Asia Pasifik di ketahui bahwa $40 \%$ peserta memiliki status gizi normal, sedangkan $60 \%$ lainnya memiliki masalah gizi dengan rincian status gizi yaitu kurus (10\%), pra obes (10\%), obes I (25\%), dan obes II (15\%). Banyaknya peserta pengabdian yang memiliki status gizi lebih pada pengabdian ini hampir sama dengan pengabdian terdahulu pada peserta pengabdian di kelurahan delima kecamatan tampan pekanbaru yaitu sebanyak 87\% mengalami obesitas (Al Sukri et all., 2020). Masalah status gizi ini akan berdampak pada status kesehatan seseorang. Salah satu upaya yang dapat dilakukan untuk mengurangi resiko sindrom metabolik adalah penerapan diet mediteranian untuk mengurangi resiko obesitas yang merupakan salah satu bagian dari sindrom metabolik (Bendall et all., 2018)

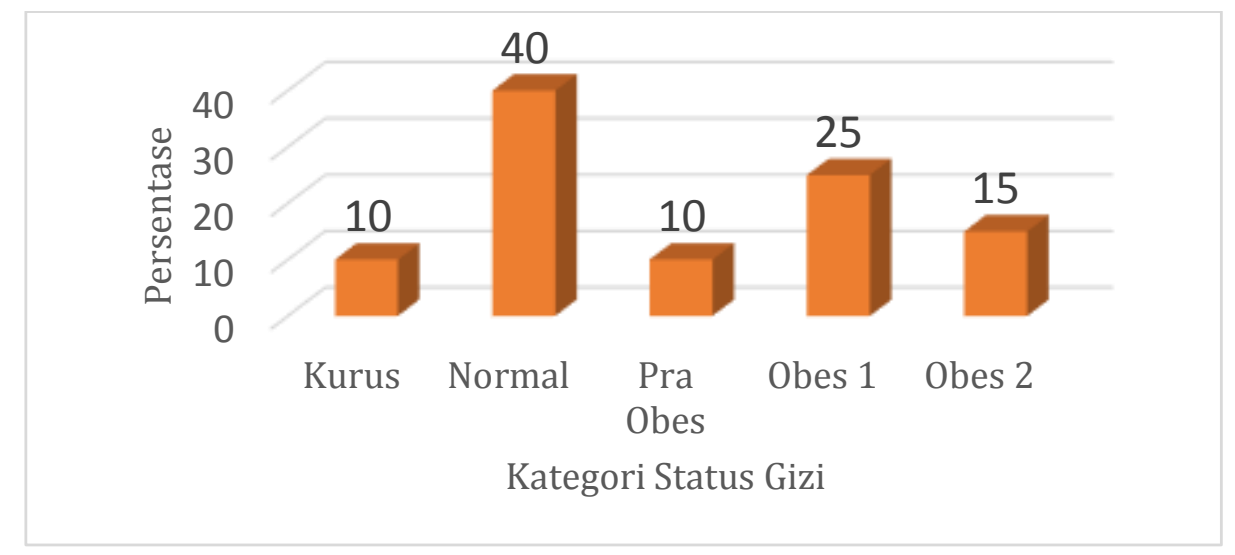

Gambar 2. Status gizi peserta

Narasumber mengawali pemaparan mengenai definisi sindrom metabolik, faktor resiko terjadinya sindrom metabolik, cara pencegahan sindrom metabolik, piramida gizi 
seimbang, anjuran membatasi konsumsi gula, garam, dan lemak, cara membaca label kemasan, informasi nilai gizi, pentingnya memperhatikan kandungan gula, garam, dan lemak dalam food labelling, serta tips memilih makanan kemasan.

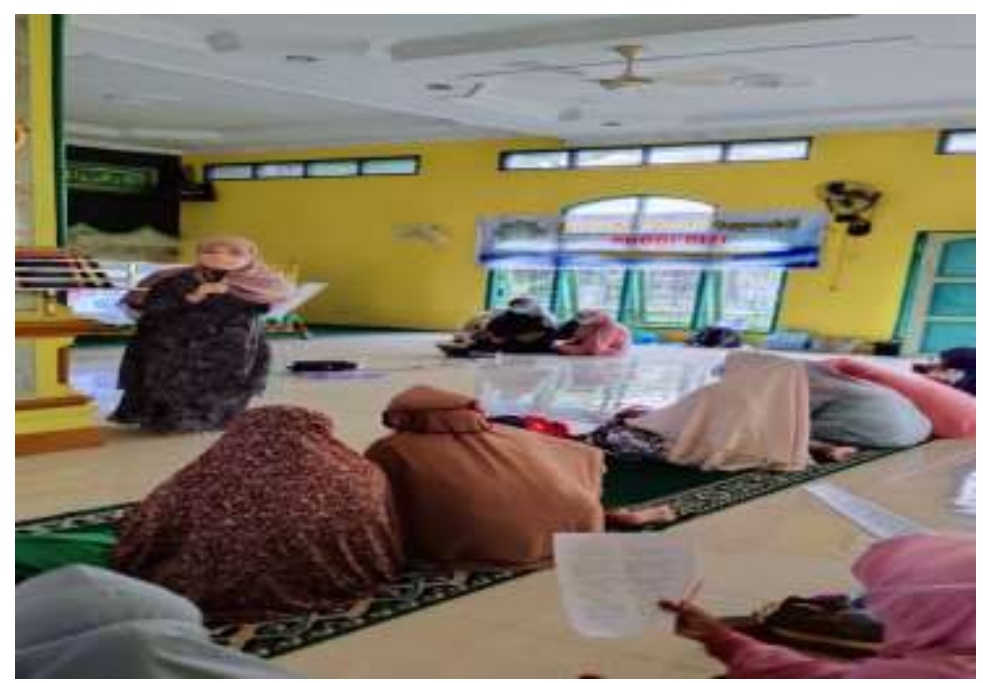

Gambar 3. Pemaparan materi

Kegiatan berlangsung lancar hingga sesi diskusi banyak pertanyaan dan tanggapan yang disampaikan oleh peserta. Beberapa peserta ada yang menanyakan apakah kandungan garam dalam makanan kemasan lebih banyak daripada penambahan garam dapur, bagaimana mengetahui kandungan gula untuk minuman kemasan, cara mengetahui kandungan bahan makanan yang aman di konsumsi, apakah konsumsi kolesterol berlebih menyebabkan stroke, berapa takaran konsumsi sayur, dampak pengolahan makanan dengan meggunakan minyak yang digoreng berulang, apakah diabetes boleh mengkonsumsi buah dan lainnya. Tim pengabdian memberikan penjelasan yang baik dari keseluruhan pertanyaan yang disampaikan oleh peserta. Pada sesi akhir pengabdian, tim mengingatkan kembali kepada seluruh peserta mengenai anjuran pembatasan gula, garam, dan lemak, hal ini sesuai dengan pesan gizi seimbang, asupan makanan harus sesuai dengan memperhitungkan jumlah kalori dan cukup melakukan aktivitas fisik. Asupan gizi seimbang ini dapat mencegah terjadinya resiko sindrom metabolik.

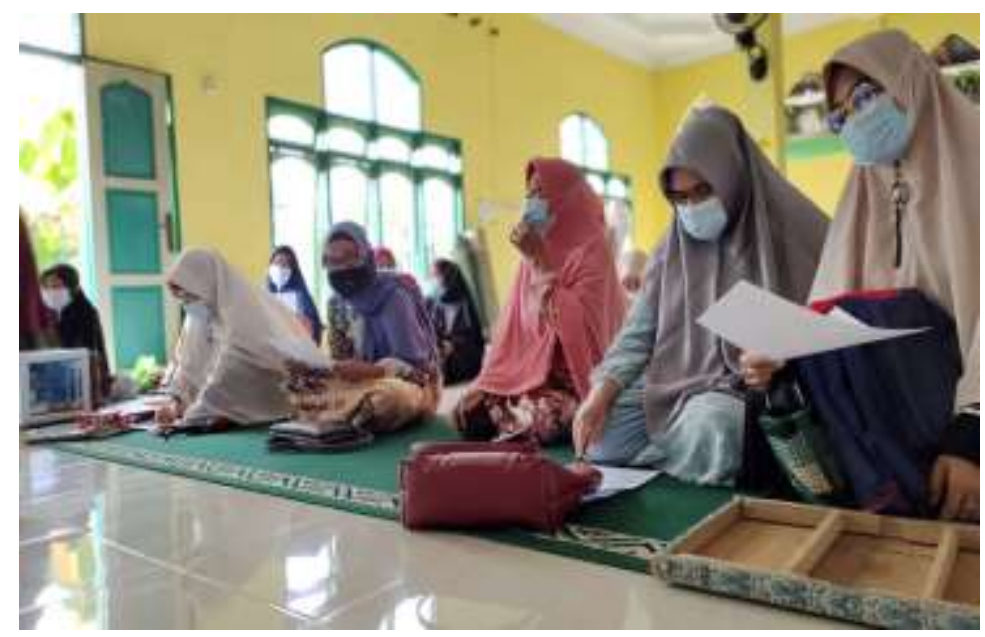

Gambar 4. Sesi Diskusi dan Tanya Jawab 


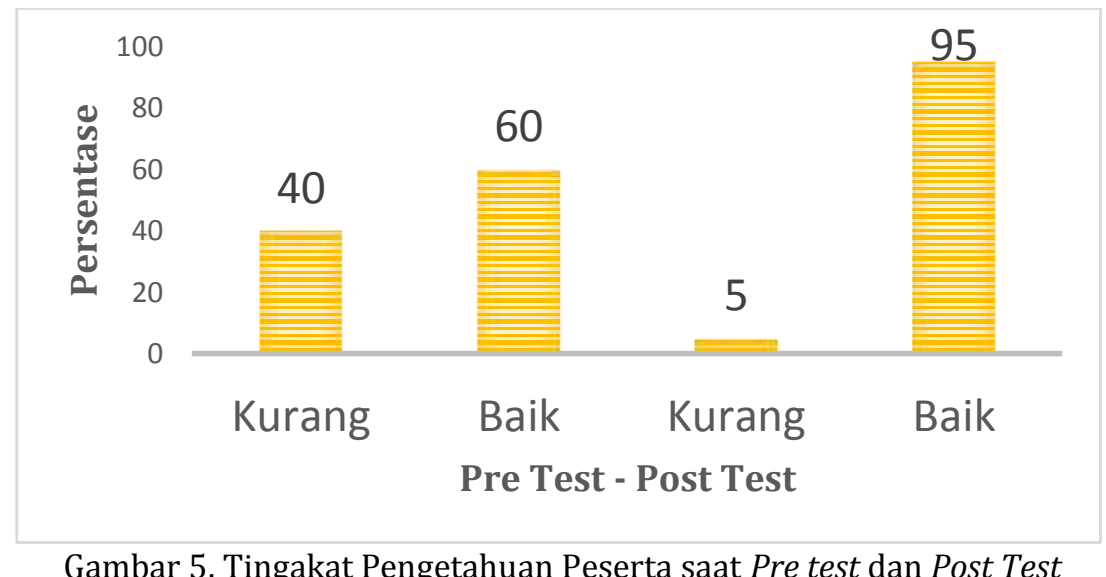

Gambar 5. Tingakat Pengetahuan Peserta saat Pre test dan Post Test

Pada kegiatan pengabdian kepada masyarakat ini juga melakukan evaluasi dengan analisis peningkatan pengetahuan peserta mengenai topik yang disampaikan. Berdasarkan pre test dan post test yang dilakukan dengan memberikan 5 pertanyaan pilihan ganda, menunjukkan bahwa terdapat peningkatan pengetahuan mengenai gula, garam, dan lemak dan kaitannya dengan sindrom metabolik (Gambar 5). Skor awal pengetahuan ibu pengajian wirid mesjid mengenai pembatasan konsumi gula, garam, dan lemak masih banyak yang rendah (40\%). Pengetahuan yang rendah bisa berpengaruh pada perilaku konsumsi gizi yang kurang tepat seperti berlebihan dalam mengkonsumsi gula, garam, dan lemak.

Hasil post test menunjukkan peningkatan pengetahuan gizi dengan kategori baik dari $60 \%$ menjadi 95\%. Sedangkan untuk pengetahuan gizi dengan kategori kurang menurun dari 40\% menjadi 5\%. Pengetahuan gizi pada penelitian ini dikategorikan menjadi baik (kategori baik dan sedang) jika nilainya $\geq 60 \%$, dan kategori pengetahuan kurang jika $<60 \%$. Nilai rata - rata skor pengetahuan awal pre test adalah 55 meningkat menjadi 90 saat akhir post test. Nilai hasil pre test ini berbeda dengan kegiatan penyuluhan mengenai gizi terkait sindrom metabolik ditempat lain dengan nilai rata-rata pada pre-test 42,12 yang mengalami peningkatan nilai post-test menjadi 68 setelah dilakukan penyuluhan (belum terlalu memuaskan) (Amiroh \& Mardyah, 2021). Untuk perubahan perilaku masyarakat terkait gizi dan kesehatan selain edukasi diperlukan pendampingan kegiatan berlanjut, dukungan kelompok masyarakat, dan dilanjutkan dengan konseling gizi terjadwal.

Faktor penghambat yang teridentifikasi ialah keterbatasan waktu persiapan antara waktu sholat ashar dan magrib, sebagian peserta mengajukan banyak pertanyaan dan ingin praktek langsung untuk memahami nilai gizi dalam makanan kemasan. Hal ini memunculkan gagasan untuk membuat kegiatan yang dipersiapkan di lapangan secara langsung untuk praktek di waktu pagi hari, bila kondisi pandemi covid 19 sudah dapat tertangani cukup kondusif. nantinya. Faktor pendukung pelaksanaan pengabdian masyarakat ini, antara lain: antusiasme peserta yang telah hadir untuk mengikuti kegiatan. Antusiasme ini tampak dari keinginan peserta yang hadir untuk bertanya berbagai persoalan mengenai materi. Semangat dan motivasi tinggi dalam mengikuti kegiatan didukung oleh semangat dan motivasi tim pengabdian. Peserta pengabdian menyambut baik untuk kegiatan dapat berlanjut dengan tema yang berbeda di pertemuan pengajian wirid masjid berikutnya

\section{KESIMPULAN}

Kegiatan pengabdian masyarakat untuk peserta pengajian wirid Mesjid Darul Amal RT 03 RW 07 Kelurahan Tuah Madani Pekanbaru Provinsi Riau berlangsung lancar. Peserta cukup banyak masuk pada ketegori usia lansia (>55 tahun) sebanyak $45 \%$ dan memiliki masalah gizi yaitu kurus (10\%), pra obes (10\%), obes I (25\%), dan Obes II (15\%). Hasil post test menunjukkan peningkatan pengetahuan gizi dengan kategori baik dari $60 \%$ menjadi $95 \%$. 
Sedangkan untuk pengetahuan gizi dengan kategori kurang menurun dari 40\% menjadi 5\%., dan evaluasi saat sesi tanya jawab dapat memahami mengenai pembatasan gula, garam, dan lemak dan kaitannya terhadap kejadian sindrom metabolik. Kegiatan ini disambut baik oleh peserta dan berharap kegiatan terus berlanjut dengan topik yang berbeda berikutnya dan disertai dengan praktek bila kondisi pandemi covid 19 dapat tertangani.

\section{DAFTAR PUSTAKA}

Al-Agili, Z. H. (2020). The Effect of Food Additives (Monosodium Glutamate - MSG) On Human Health - A Critical Review. , 31(1), 362-369. من في است ترجع http://uoajournal.com/index.php/maarif/article/view/23

Alsukri, S., Syuryadi, N., \& Ernalia, Y. (2020). Peningkatan Pengetahuan Gizi Seimbang Dan Mitos Seputar Gizi Pada Keluarga Pra-Sejahtera Di Kelurahan Delima Pekanbaru. Martabe: Jurnal Pengabdian Kepada Masyarakat, 3(1), 108-115.

Amiroh, A., Dwiyana, P., \& Mardiyah, S. (2021). Edukasi Gizi Pola Konsumsi Rendah Gula, Garam, Lemak (GGL) pada Remaja. Community Empowerment, 6(4), 595-601.

Bendall, C.L.; Mayr, H.L.; Opie, R.S.; Bes-Rastrollo, M.; Itsiopoulos, C.; Thomas, C.J. (2018) Central obesity and the Mediterranean diet: A systematic review of intervention trials. Crit. Rev. Food Sci. Nutr., 58, 3070-3084.

Fenty F, Widayati A, Virginia DM, Hendra P. (2016). Metabolic syndrome among Adults in Rural Area. Indones J Clin Pathol Med Lab. 2016;22(3):254-7. doi: 10.1016/j.pe.09.007

Harrison, S., Couture, P., \& Lamarche, B. (2020). Diet quality, saturated fat and metabolic syndrome. Nutrients, 12(11), 3232.

Ismawanti, Z., Safitri, W., \& Andarbeni, D. P. (2020). Pembatasan Konsumsi Gula, Garam Dan Lemak Melalui Cakram Edukasi Gizi Seimbang Pada Penderita Diabetes Mellitus Tipe 2. Jurnal Pengabdian Kepada Masyarakat Ungu (ABDI KE UNGU), 2(2), 63-67.

Kementerian Kesehatan RI [Kemkes]. (2013). Riset Kesehatan Dasar Provinsi Riau 2013. Jakarta: Badan Litbang Kesehatan, Kementerian Kesehatan RI.

.. (2013b). Pencantuman Informasi Kandungan Gula, Garam, dan Lemak serta Pesan

Kesehatan untuk Pangan Olahan dan Pangan Siap Saji. Peraturan Menteri Kesehatan Republik Indonesia Nomor 30 Tahun 2013. Kemenkes RI (2014). Pedoman Gizi Seimbang. Jakarta.

RI.

(2018). Riskesdas 2018. Jakarta: Badan Litbang Kesehatan, Kementerian Kesehatan

Masrikhiyah, R. (2020). Peningkatan Pengetahuan Ibu Mengenai Gizi Seimbang Dalam Pemenuhan Gizi Keluarga. Dinamisia: Jurnal Pengabdian Kepada Masyarakat, 4(3), 476-481.

Nurzakiah, N. (2021). Literature Review: Pengaruh Pola Makan Terhadap Sindrom Metabolic. ANNur: Jurnal Kajian dan Pengembangan Kesehatan Masyarakat, 1(2), 215-224.

Rini, S. (2015). Sindrom metabolik. Jurnal Majority, 4(4).

Semnani-Azad, Z., Khan, T. A., Mejia, S. B., de Souza, R. J., Leiter, L. A., Kendall, C. W., ... \& Sievenpiper, J. L. (2020). Association of major food sources of fructose-containing sugars with incident metabolic syndrome: a systematic review and meta-analysis. JAMA network open, 3(7), e209993-e20999.

Widayati, A., Fenty, F., Linawati, Y., \& Christasani, P. D. (2020). Pengetahuan dan Profil Gaya Hidup Sehat pada Orang Dewasa di Pedesaan di Daerah Istimewa Yogyakarta. Indonesian Journal of Clinical Pharmacy, 9(2), 118-127.

Utami, Y., Dani, R., Ernalia, Y. (2014). Gambaran Asupan Gizi pada Penderita Sindrom Metabolik di Rw 04 Kelurahan Sidomulyo Barat Kecamatan Tampan Kota Pekanbaru. Jurnal Online Mahasiswa (JOM) Bidang Kedokteran Vol 1, No 2 (2014).

Zahtamal, Z., Prabandari, Y. S., \& Setyawati, L. (2014). Prevalensi sindrom metabolik pada pekerja perusahaan. Kesmas: Jurnal Kesehatan Masyarakat Nasional (National Public Health Journal), 9(2), 113-120. 